\title{
Etniczność i narodowość rdzennych mieszkańców Górnego Śląska po 1989 roku
}

\begin{abstract}
Popieliński Paweł, Etniczność i narodowość rdzennych mieszkańców Górnego Ślaska po 1989 roku (Ethnicity and Nationality of the Indigenous Population of Upper Silesia after 1989). „Poznańskie Studia Slawistyczne” 8. Poznań 2015. Publishing House of the Poznań Society for the Advancement of the Arts and Sciences, pp. 137-151. ISSN 2084-3011.

In the article, the author describes an evaluation regarding the identity of the indigenous population of Upper Silesia against the specific of this region background. First of all, he focuses on the evaluation concerning the identity of this group after 1989 - on the multidimensional Silesianess. He shows the phenomenon of joining the German minority with many Silesians, which creates the regional movements especially Silesian organizations that promote Silesianess and strive for acknowledgment of the Silesian nationality and Silesian dialect for the language. In retrospect, an increasing popularity of such organizations may be noticed among the Silesians due to their nationality declarations. According to census 2002 and 2011, the Silesians represent the largest minority group that so far has unregulated legal status. For years, Silesian organizations endeavor to change this situation. They try to dispose the Polish authorities to amend the act on national and ethnic minorities and on the regional languages to find in the act the Silesians and their dialect receive the language status.
\end{abstract}

KeYwords: Silesians; Upper Silesia; ethnicity; nationality; Silesian organizations; Silesianess; Silesian nationality; German minority

\section{Wstęp}

Ślązacy to rdzenna ludność Górnego Śląska, żyjąca w województwach śląskim i opolskim ${ }^{1}$. Badacze szacują, że w skład łącznej liczby - około 5,7 mln - mieszkańców tych województw wchodzi 1,2-1,5 mln etnicznych

${ }^{1}$ Tereny historycznego Górnego Śląska znajdują się także po czeskiej stronie (kraj morawsko-śląski) - głównie Śląsk Opawski i kraik hulczyński - żyje tam niewielka liczebnie ludność rodzima (ma ona nieco odmienną specyfikę od tej zamieszkującej na terenie Polski). Ze względu na ograniczenie rozmiaru artykułu nie będzie ona rozpatrywana. Więcej na temat tożsamości (cf. Jerczyński 2013). 
Ślązaków (Sakson 2012: 1). Są Polakami, Niemcami, ale istnieje także duża grupa, która nie utożsamia się z żadnym z tych narodów. Określają się jako Ślązacy i wskazują swoją odrębność wobec narodu polskiego czy niemieckiego. Należy podkreślić, że wszystkich Ślązaków, niezależnie od ich deklarowanej tożsamości narodowej (czy jej braku), łączy szeroko pojęta śląskość, która przejawia się chociażby w poczuciu przywiązania do regionu - małej ojczyzny (Heimatu), tożsamości etnicznej, gwary śląskiej, zwyczajów i tradycji itp.

Kultura śląska ukształtowała się w ciągu wielu stuleci w różnych organizmach państwowych i w interakcji z sąsiednimi kulturami narodowymi. Łączy elementy tych kultur (polskiej, niemieckiej, czeskiej) i kultury lokalnej oraz stanowi, jako jej główny czynnik, o tożsamości śląskiej. Ślązacy bywają określani jako grupa etniczna, choć znaczna ich część chce zostać uznana za odrębny naród - śląski. Zmiany społeczno-polityczne po 1989 roku przyczyniły się do ewaluacji tożsamości etniczno-narodowej miejscowego społeczeństwa, a tym samym do pojawienia się osób, które myślą o sobie w kategoriach - nieuznawanej prawnie przez państwo polskie - narodowości śląskiej. To zjawisko socjologiczne można zauważyć chociażby w wynikach spisów powszechnych, przeprowadzonych w naszym kraju w 2002 i 2011 roku, w których duża grupa deklaruje narodowość śląską.

\section{Specyfika Górnego Śląska i jego rodzimych mieszkańców}

Górny Śląsk od wieków podlegał oddziaływaniom rozmaitych systemów kulturowych, polityczno-administracyjnych i gospodarczych. Dochodziło tu do przenikania tradycji o zróżnicowanej proweniencji. Z tego powodu rdzennych mieszkańców cechują niejednoznaczne, różnorodne opcje narodowe, a i nacjonalny indyferentyzm nie jest wśród nich zjawiskiem marginalnym.

Historycznie region ten był ulokowany na peryferiach wszystkich organizmów państwowych. Mowa tu przede wszystkim o peryferyjności politycznej i kulturowej. W ciągu ostatnich stuleci stał się on wielkim i ważnym zagłębiem przemysłowym najpierw Prus, później Rzeszy Niemieckiej, a obecnie Polski. Charakteryzował go jednak słaby rozwój 
kulturowy połączony z niskim odsetkiem wykształconej elity (Szczepański 1998: 7).

W państwie niemieckim Ślązacy byli najliczniejszą grupą mającą poczucie wyraźnej odrębności od Niemców, niepoczuwającą się jednak do silnej jedności z narodem polskim. Stanisław Ossowski twierdził:

Jest szeroka zbiorowość ludzi miejscowych, których polskość nie jest polskością ideologiczną, lecz obyczajową. Inaczej mówiąc: jest to gromada, gdzie elementy kulturowe polskości w życiu, w zachowaniu się, nie są pielęgnowane jako wyraz przekonania o łączności z polskim narodem, lecz są składnikiem miejscowego folkloru, składnikami swojskiej kultury wyodrębniającej tę zbiorowość od Niemców (Ossowski 1984: 102).

Zarówno Niemcy do 1945 roku, jak i Polacy - zwłaszcza po II wojnie światowej - przy zastosowaniu różnych metod i środków dążyli do pozyskania ludności rodzimej, to znaczy usiłowali w możliwie krótkim czasie stworzyć z nich stuprocentowych Niemców lub Polaków, tymczasem poddawani tym zabiegom mieszkańcy nie czuli się ani Niemcami, ani Polakami, lecz Ślązakami. Po 1945 roku w pierwszych powojennych latach doznane niesprawiedliwości, pośpiesznie i nieudolnie prowadzona polonizacja (naciski polonizacyjne oraz represje i praktyki dyskryminacyjne), ekonomiczna pozycja państwa niemieckiego i wielorakie tego konsekwencje zadecydowały o ukształtowaniu proniemieckiego dyskursu wśród znacznej części mieszkańców Górnego Śląska (Kurcz 1993: 184-185). Zwiększał się dystans dzielący Ślązaków i Polaków oraz subiektywne poczucie bliskości z Niemcami. Identyfikacja ta jest tym łatwiejsza, że Ślązacy mają inne społeczne wyobrażenie o Niemcach niż ludność napływowa. Dla nich byli to sąsiedzi, a nie obca grupa. W wyniku konfrontacji z Polakami przybyłymi na Górny Śląsk po II wojnie światowej zmniejszyło się poczucie dystansu społecznego wobec Niemców, którzy zaczęli być traktowani jako przedstawiciele tej samej kultury, bardziej „swoi” niż Polacy. To, co oddalało od Polaków, przybliżało do Niemców. Przed 1945 rokiem było odwrotnie - to, co oddalało od Niemców, zbliżało do Polaków (Nijakowski 2006: 138-139). Po II wojnie światowej wśród większości ludności rodzimej można było zauważyć postawę proniemiecką. 


\section{3. Ślązacy i ewaluacja ich tożsamości w latach dziewięćdziesiątych XX wieku - ruch mniejszości niemieckiej}

W czasach peerelowskich Ślązacy, Mazurzy czy Warmiacy, powołując się na pochodzenie niemieckie, decydowali się masowo migrować do Niemiec - głównie do RFN, natomiast na początku lat dziewięćdziesiątych $\mathrm{XX}$ wieku znaczna ich część postanowiła z różnych względów wstąpić do stowarzyszeń mniejszości niemieckiej. Podpisując deklaracje członkowskie, określili się jako Niemcy. Na podstawie przeprowadzonych badań socjologicznych (m.in. przez Danutę Berlińską i Antoninę Kłoskowską) na początku lat dziewięćdziesiątych ubiegłego stulecia można było stwierdzić odnowienie więzi z Niemcami jako środka służącego przezwyciężeniu poczucia upośledzenia tej grupy. Procesy demokratyzacji państwa polskiego i upodmiotowienie miejscowego społeczeństwa w ramach mniejszości niemieckiej zainicjowały przezwyciężenie izolacjonizmu Ślązaków. Powstanie ruchu mniejszości niemieckiej było zwieńczeniem długotrwałego procesu krystalizacji silnego poczucia odrębności Ślązaków od Polaków (Berlińska 1999: 59). Na marginesie warto dodać, że organizacje mniejszościowe wyznaczyły sobie za cel m.in. odbudowanie społecznej aktywności ludności rodzimej na bazie niemieckiej tożsamości narodowej.

Od wielu lat można zauważyć, że deklaracje członków tych organizacji co do identyfikacji narodowej nie są już tak jednoznaczne, jak to miało miejsce na początku lat dziewięćdziesiątych XX wieku, kiedy mówili oni o sobie: „Jesteśmy Niemcami”. Fakt ten może wynikać m.in. z kryzysu tożsamości. Obecnie czują się oni np. Ślązakami, Mazurami czy Warmiakami albo Ślązakami, Mazurami, Warmiakami niemieckiego pochodzenia i/lub Niemcami. Należy zaznaczyć, że znacznie spadła liczebność mniejszości niemieckiej w porównaniu z latami nagłego jej wzrostu w pierwszej połowie lat dziewięćdziesiątych ubiegłego stulecia.

Ogólnie rzecz biorąc, szacuje się, że ponad 90\% członków mniejszości niemieckiej to osoby wchodzące w skład macierzystej populacji (przede wszystkim Ślązacy oraz Mazurzy i Warmiacy). W wielu przypadkach mają labilny poziom tożsamości. Na Górnym Śląsku przejawem tego stanu rzeczy mogą być w pewnym stopniu deklaracje narodowości śląskiej podczas przeprowadzonego spisu powszechnego w latach 2002 i w 2011. 
Ślązacy mają zarówno polskie, jak i niemieckie korzenie oraz tradycje. Konstytutywną podstawą ich tożsamości jest śląskość, uzupełniona przede wszystkim o elementy niemieckie i polskie. Te dwa komponenty z różną siłą występują w pokoleniu najstarszym i najmłodszym. Stąd o tym, czy dana osoba uważa się za Polaka lub Niemca, czy też po prostu za Ślązaka, decyduje osobista historia życia każdego człowieka. Inaczej nie można byłoby wyjaśnić, dlaczego w jednej rodzinie istnieją stronnicy tej czy innej opcji (Wańkowska-Sobiesiak 2006: 84).

\section{4. Ślązacy i procesy tożsamościowe od początku lat dziewięćdziesiątych XX wieku do dzisiaj - pojawienie się ruchów regionalnych i odrębności Ślązaków}

Transformacja społeczno-polityczna w Polsce po 1989 roku dawała szansę na zmianę podejścia władz centralnych do Górnego Śląska i jego ludności rodzimej. Rdzenni mieszkańcy mieli duże oczekiwania wobec nowych demokratycznych władz. Uważali, że w okresie PRL spychano ich na peryferyjne pozycje społeczne, a region wyzyskiwano; spodziewali się zmian na lepsze w obu sferach. To wszystko przyczyniło się do reaktywacji lokalnych ruchów na początku lat dziewięćdziesiątych ubiegłego stulecia, co połączone ze wzrostem tendencji autonomicznych oraz podkreślaniem odrębności kulturowej Ślązaków, wywołało liczne kontrowersje wśród społeczeństwa większościowego (Bałdys 2013: 132).

Zapoczątkowana transformacja przyczyniła się do odrodzenia ruchów regionalnych na Górnym Śląsku. Część Ślązaków zaczęła wysuwać postulaty uznania swej odrębności od Polaków czy Niemców oraz wprowadzenia autonomii w regionie, jak miało to miejsce w okresie dwudziestolecia międzywojennego - w II RP. Do dziś działacze tych ruchów zabiegają o uznanie ich za grupę narodowościową. Wyrazem tej dążności jest zarejestrowany Ruch Autonomii Śląska (RAŚ), powstanie Związku Ludności Narodowości Śląskiej w Katowicach (ZLNŚ), który od wielu lat stara się o rejestrację, oraz zarejestrowane kilka lat temu w Opolu Stowarzyszenie Osób Narodowości Śląskiej (SONŚ) (Śliz, Szczepański 2013: 117-118; więcej na temat wspomnianych organizacji śląskich w dalszej części artykułu). Liderzy organizacji chętnie powołują się na fakt, że 
z socjologicznego punktu widzenia grupy etniczne bywają uznawane za zalążki narodów. Jak pisze Antonina Kłoskowska: „Tworzenie się zbiorowości narodowych na podstawach etnicznych jest procesem historycznym o różnorodnych wariantach. Wielu autorów zdecydowanie akceptuje etniczne źródła narodów (...). Grupę etniczną traktuje się jako fazę protonarodu" (Kłoskowska 1996: 46).

\section{Deklaracje etniczno-narodowościowe Ślązaków podczas Narodowych Spisów Powszechnych w 2002 i 2011 roku}

Formalnie istnienie narodowości śląskiej potwierdziły dane Narodowego Spisu Powszechnego z roku 2002 i 2011, chociaż zgodnie z polskim prawem nie istnieje taka narodowość. Ponadto Ślązacy nie zostali uznani ani za mniejszość etniczną, ani mniejszość narodową w myśl Ustawy o mniejszościach narodowych i etnicznych oraz o języku regionalnym z 2005 roku, mimo że są najbardziej widoczną i najliczniejszą mniejszością (zgodnie z wynikami niniejszych spisów przeprowadzonych na Górnym Śląsku).

W spisie powszechnym w 2002 roku należało wskazać tylko jedną narodowość, a w 2011 roku można było jednocześnie zadeklarować narodowość i przynależność do wielu wspólnot narodowych lub etnicznych. Warto zwrócić uwagę, że wprowadzenie do ankiety GUS kategorii narodowej i etnicznej ,śląska” - podczas Narodowego Spisu Powszechnego 2011 - jest sprzeczne z wyrokami sądowymi, które formalnie nie uznają istnienia narodowości śląskiej. Niemniej jednak kategoria narodowa i etniczna „śląska” została wprowadzona zgodnie z Ustawą o narodowym spisie powszechnym ludności i mieszkań w 2011 roku, w której przez narodowość - przynależność narodową lub etniczną - rozumie się „,deklaratywną, opartą na subiektywnym odczuciu, indywidualną cechę każdego człowieka, wyrażającą jego związek emocjonalny, kulturowy lub związany z pochodzeniem rodziców, określonym narodem lub wspólnotą etniczną" (Ustawa o narodowym spisie...). Dzięki niej umożliwiono deklarowanie narodowości śląskiej i w rubrykach przy obydwu pytaniach pojawiła się właśnie ta kategoria.

Według danych spisu ludności z 2002 roku narodowość tę zadeklarowały 173153 osoby - 148,5 tys. osób w województwie śląskim (ponad 3\% ogółu ludności województwa), a w województwie opolskim 24,2 tys. osób 
(ponad 2\% ogółu ludności województwa). Dla porównania: przynależność do mniejszości niemieckiej zadeklarowało w spisie 152,9 tys. osób, w tym 31,9 tys. osób w województwie śląskim (co stanowi ok. 1\% ogółu ludności województwa), a w województwie opolskim 106,9 tys. osób (ok. 10\% ogółu ludności województwa) (Raport... 2012: 105-106).

Pytania o identyfikacje narodowo-etniczne w spisie z 2011 roku zapewne przyczyniły się do pełniejszego wyrażenia złożonego poczucia tożsamości narodowo-etnicznych oraz uniknięcia trudnych dylematów identyfikacyjnych. Podczas spisu ludności w 2011 roku odnotowano w sumie 847 tys. osób deklarujących przynależność śląską (w województwie śląskim ponad 722 tys. osób, w opolskim 106,4 tys. osób). Na pierwsze pytanie dotyczące deklaracji identyfikacji narodowo-etnicznej - śląską narodowość podało 436 tys. osób (w województwie śląskim 378,5 tys., w opolskim 52,8 tys. osób), natomiast w drugim pytaniu tego rodzaju - śląską podało 411 tys. osób (w województwie śląskim 343,6 tys., w opolskim 53,6 tys. osób). Wyłącznie narodowość śląską zadeklarowało 376 tys. osób (w województwie śląskim 331,2 tys. osób, w opolskim 41,4 tys. osób), natomiast 431 tys. obywateli naszego kraju zadeklarowało narodowość śląską i jednocześnie polską (w województwie śląskim 376,6 tys., w opolskim 39,5 tys. osób). Była to najczęściej podawana identyfikacja śląska wraz z inną narodowością. Narodowość śląską wspólnie z narodowością niepolską zadeklarowało 40 tys. osób (Ludność... 2013c: 91; Ludność... 2013a: 68; Ludność... 2013b: 60).

Narodowość niemiecką odnotowano w spisie w 148 tys. przypadków (w województwie śląskim 35 tys. osób, opolskim 78,6 tys. osób). Na pierwsze pytanie dotyczące deklaracji identyfikacji narodowo-etnicznej - narodowość niemiecką podało 74 tys. osób (w województwie śląskim 14,9 tys. osób, opolskim 51,4 tys. osób), natomiast w drugim tego rodzaju pytaniu - narodowość niemiecką podało 73 tys. osób (w województwie śląskim 20,3 tys. osób, opolskim 27,2 tys. osób). Wyłącznie narodowość niemiecką zadeklarowało 45 tys. osób (w województwie śląskim 8,6 tys. osób, opolskim 30,1 tys. osób), a narodowość jednocześnie niemiecką i polską podało 64 tys. obywateli RP (w województwie śląskim 13,3 tys. osób, opolskim 23,1 tys. osób). Identyfikację niemiecką najczęściej wskazywano łącznie z polską; wspólnie z niepolską podało 39 tys. osób (Ludność... 2013c: 91; Ludność... 2013a: 68; Ludność... 2013b: 60). 
Mimo że w spisach powszechnych z 2002 i z 2011 roku zastosowano różne metodologie, to dane uzyskane podczas Narodowego Spisu Powszechnego z 2011 roku w zestawieniu z poprzednim spisem ludności potwierdziły tendencję spadkową wśród liczby osób deklarujących narodowość niemiecką oraz odnotowały znaczny wzrost liczby osób deklarujących narodowość śląską.

Przed przeprowadzeniem obydwu spisów powszechnych wśród przedstawicieli mniejszości niemieckiej - zwłaszcza z Górnego Śląska - istniały obawy, czy jej członkowie będą przyznawać się do swego pochodzenia i czy niektórzy z nich nie podadzą narodowości śląskiej zamiast niemieckiej. Reprezentanci tej grupy liczyli, że ich członkowie odpowiedzą zgodnie z sumieniem na pierwsze pytanie o narodowość - podając niemiecką, a pominą drugie lub ewentualnie odpowiedzą: „narodowość śląska”, przyjmując zasadę, że każdy Niemiec żyjący na Śląsku jest także Ślązakiem i ma prawo do zadeklarowania swojej identyfikacji regionalnej.

Wpływ na dużą liczbę osób deklarujących narodowość śląską w 2011 roku, w porównaniu z poprzednim, przeprowadzonym w 2002 roku, może mieć przede wszystkim atrakcyjność ruchów społecznych na rzecz śląskości, a także w pewnej mierze słowa prezesa Prawa i Sprawiedliwości Jarosława Kaczyńskiego o narodowości śląskiej jako „zakamuflowanej opcji niemieckiej" (Kaczyński 2011). Wystąpienie to przyczyniło się do większego i śmielszego podawania narodowości śląskiej przez społeczność miejscową Górnego Śląska podczas spisu. Stygmatyzacja macierzystej populacji sprawiła, że wiele osób zadeklarowało podczas ostatniego spisu powszechnego - w ramach protestu - narodowość śląską zamiast niemieckiej czy polskiej lub też przede wszystkim zaznaczało śląskość, a następnie niemieckość lub polskość. Paradoksalnie, prezes PiS wniósł swoimi słowami znaczny wkład w rozbudzenie śląskości: opcja ta zyskała niezwykłą reklamę.

Podawanie w obu spisach narodowości śląskiej przez mieszkańców Górnego Śląska (w tym przez część członków mniejszości niemieckiej) sprzyjało Ruchowi Autonomii Śląska i innym śląskim organizacjom, które dążą m.in. do uzyskania przez Górny Śląsk autonomii i/lub do uznania przez władze polskie śląskiej narodowości. Ugrupowania te cieszą się od kilkunastu lat coraz większą popularnością. Dla wielu młodych ludzi są one przede wszystkim ruchami nowocześniejszymi, bardziej dynamicznymi 
i atrakcyjniejszymi od organizacji mniejszości niemieckiej na Górnym Śląsku. Według wielu członków tej mniejszości podawanie w spisie narodowości śląskiej czy też nawet wstąpienie do którejś z organizacji śląskich nie jest zdradą niemieckości, lecz podkreśleniem śląskości.

Przeprowadzony spis powszechny w 2011 roku wykazał, że osoby deklarujące narodowość śląską i posługujące się śląską mową stanowią największą grupę mniejszościową w Polsce. Po raz drugi w ciągu dziesięciu lat Ślązacy w oficjalnych państwowych statystykach pojawili się w charakterze największej grupy mniejszościowej, jednak wciąż o nieuregulowanym statusie prawnym. Należy zauważyć, że przezwyciężyli oni kompleks niższości i nie chcą być już postrzegani jako wieczne ofiary wojny, dyskryminacji i transformacji. Ponadto wielu Ślązaków (w tym część członków mniejszości niemieckiej) nie rozgranicza pojęcia etniczności od regionalności czy narodowości: swoją śląskość traktują przede wszystkim jako poczucie przynależności do regionu. Deklarowanie narodowości śląskiej było i jest zjawiskiem społecznym, wyrazem protestu przeciwko brakowi zainteresowania sprawami Śląska, sprzeciwem wobec warunków bytowych i kondycji ekonomicznej Górnego Śląska - przede wszystkim bezrobocia i zamykania kopalń oraz dużych zakładów pracy (cf. Sekuła, Jałowiecki, Majewski, Żelazny 2012).

Wśród rodzimych mieszkańców tego regionu, zwłaszcza na obszarze przemysłowego Górnego Śląska (czyli ziemiach należących od 1922 roku do Polski, na znacznej części obecnego województwa śląskiego), coraz większą popularnością cieszy się opcja śląska. We wschodniej części województwa opolskiego i w zachodniej województwa śląskiego, czyli w bastionach mniejszości niemieckiej, można zauważyć, że dominująca tam przez lata opcja niemiecka (na terenach należących do Niemiec do 1945 roku) zaczyna przegrywać coraz częściej ze śląską. Pomiędzy mniejszością niemiecką a organizacjami działającymi na rzecz śląskości istnieje wyraźna rywalizacja. Przedstawiciele mniejszości niemieckiej nie tylko nie wspierają, ale są wręcz przeciwni śląskim organizacjom, które dążą do uzyskania przez Ślązaków statusu mniejszości narodowej bądź etnicznej lub też uznania gwary śląskiej za język regionalny. 


\section{Organizacje śląskie starające się o prawne uznanie narodowości śląskiej}

Najstarszą z organizacji śląskich, starających się o prawne uznanie Ślązaków za narodowość, jest Ruch Autonomii Śląska. Dąży on zwłaszcza do uzyskania przez Górny Śląsk autonomii, ale także m.in. do uznania śląskiej narodowości. RAŚ utworzono w 1991 roku, jednak dopiero w roku 2001 został wpisany do Krajowego Rejestru Sądowego. Deklarowanym celem Ruchu jest rozbudzanie i promowanie śląskiej tożsamości, popularyzowanie górnośląskiego kulturowego dziedzictwa oraz utworzenie autonomicznego regionu w historycznych granicach Górnego Śląska (Sejm Śląski, regionalny rząd i Skarb Śląski) w ramach Rzeczypospolitej Polskiej (dyplomacja, wojsko i polityka monetarna). Precedensem miałoby być posiadanie przez województwo śląskie autonomii w okresie II Rzeczypospolitej. Omawiany ruch aspiruje ponadto do reprezentowania interesów wszystkich Ślązaków, niezależnie od ich opcji narodowej, religijnej czy językowej; przed spisem powszechnym w 2002 roku z sukcesem przeprowadził akcję po hasłem: „Masz prawo zadeklarować narodowość śląską”. RAŚ działa na rzecz społeczności lokalnej, wspiera inicjatywy edukacyjne i kulturalne, propaguje idee autonomii i regionalizmu, organizuje Górnośląskie Dni Dziedzictwa, akcje ratowania zabytków poprzemysłowych itp. Od wyborów samorządowych w 2010 roku RAŚ stał się czwartą siłą polityczną w województwie śląskim. Wprowadził swoich przedstawicieli do niektórych rad gminnych i zdobył trzy mandaty do sejmiku województwa. Od 2010 do 2013 roku przewodniczący RAŚ, Jerzy Gorzelik, piastował stanowisko członka Zarządu Województwa Śląskiego.

Kwestia narodu i narodowości śląskiej pojawiła się w debacie publicznej w związku z powstaniem i staraniami o rejestrację Związku Ludności Narodowości Śląskiej. Organizacja ta od wielu lat kieruje do Europejskiego Trybunału Praw Człowieka w Strasburgu skargi w sprawie łamania przez rząd polski praw do swobodnego zrzeszania się. Wszystkie zostały oddalone, oprócz ostatniej, która od kilku lat czeka na rozpatrzenie. Związek ten powstał w 1996 roku, jego celem jest rozbudzanie i ugruntowywanie świadomości narodowej Ślązaków, ochrona praw etnicznych osób deklarujących przynależność do tej narodowości, odrodzenie śląskiej kultury i propagowanie wiedzy o regionie. Związek dąży do uznania przez władze 
polskie narodowości śląskiej oraz nadanie gwarze śląskiej statusu języka regionalnego. W 2004 roku nowy komitet założycielski związku zrezygnował z definiowania go jako organizacji śląskiej mniejszości narodowej, jednak pomimo wielu zmian w statucie, jak dotąd ruch nie został wpisany do Krajowego Rejestru Stowarzyszeń. Polskie sądy wykazują w jego statucie fragmenty sprzeczne z polskim stanem prawnym: zarejestrowanie organizacji wiązałoby się z uznaniem śląskiej mniejszości narodowej/narodowości śląskiej. Uznanie określonej grupy za naród niesie ze sobą istotne konsekwencje polityczne, ponieważ otwiera możliwość domagania się prawa do własnej suwerenności. Automatycznie uznanie określonej grupy za naród powoduje, zgodnie z polskim prawodawstwem (ale i nie tylko), uzyskanie przywilejów wyborczych zagwarantowanych dla mniejszości narodowych (Baranowska 2013: 44).

To, co nie udało się przez 15 lat nieformalnie działającemu Związkowi Ludności Narodowości Śląskiej z siedzibą w Katowicach, powiodło się grupie młodych działaczy z Opola i okolic (Michna 2013: 154). W grudniu 2011 roku Sąd Rejonowy w Opolu wydał precedensowe postanowienie o rejestracji Stowarzyszenia Osób Narodowości Śląskiej. Organizacja ta ma na celu rozbudzanie i ugruntowanie świadomości narodowej Ślązaków, odrodzenie kultury śląskiej i kształtowanie pozytywnego wizerunku regionu i ludności, a także rozgraniczenie kwestii narodowości śląskiej i autonomii regionu, ponieważ nie każdy Ślązak interesuje się polityką i popiera autonomię. W odróżnieniu od Ruchu Autonomii Śląskiej, omawiane stowarzyszenie nie prowadzi działalności politycznej i, zgodnie z deklaracjami, nie zamierza jej rozpoczynać. W uzasadnieniu rejestracji opolski sąd stwierdził, że w statucie ruchu nie ma pojęcia „naród śląski” ani „śląska mniejszość narodowa", natomiast obowiązujący stan prawny dopuszcza twierdzenie o samym sobie, że jest się narodowości śląskiej. Sama deklaracja tożsamości nie tworzy nowego narodu ani mniejszości narodowej. Sąd orzekł, że utworzenie stowarzyszenia zrzeszającego osoby o poczuciu śląskiej narodowości może oznaczać jedynie powstanie takiej osobowości prawnej, nie oznacza jednak ani zinstytucjonalizowania określonej narodowości, ani uznania w porządku prawnym nowego narodu czy też mniejszości narodowej, pozwalającej na korzystanie z przywilejów przysługujących mniejszościom. W styczniu 2012 roku prokuratura opolska wniosła jednak apelację w sprawie legalizacji stowarzyszenia, uzasadniając, że decyzja 
o rejestracji stoi w sprzeczności z Ustawą o mniejszościach narodowych i etnicznych, w których śląska narodowość nie występuje. W grudniu 2013 roku Sąd Najwyższy nakazał rozpatrzenie rejestracji stowarzyszenia przez Sąd Okręgowy, argumentując przy tym, że jego nazwa wprowadza w błąd, ponieważ formalnie nie istnieje naród śląski. 7 marca 2014 roku Sąd Okręgowy w Opolu podtrzymał argumentację Sądu Najwyższego, jednak nie wykreślił stowarzyszenia z rejestru i przekazał sprawę do rozpatrzenia przez Sąd Rejonowy („Newsletter...” 2014: 1).

Ślązacy chcący oficjalnego uznania ludności rodzimej za naród, W znacznym stopniu skupiają się na kultywowaniu w regionie śląskości, która wyraża się we wszelkiego rodzaju festynach, biesiadach śląskich, kuchni śląskiej, kultywowanych zwyczajach i lokalnych uroczystościach (w tym uroczyste świętowanie odpustów parafialnych i innych świąt kościelnych). Warto zwrócić uwagę, że zwłaszcza w przemysłowej (katowickiej) części Górnego Śląska zaczynają się pojawiać śląskie napisy na ulicach, sklepach lub automatach. Dziennikarze w audycjach radiowych, telewizyjnych i w prasie posługują się gwarą, w Internecie pojawiają się śląskie strony i programy, coraz częściej widać śląskie flagi lub emblematy na samochodach (zwłaszcza herb Górnego Śląska).

Społeczeństwo większościowe, od kilku pokoleń żyjące w regionie razem ze Ślązakami, jest przyzwyczajone do inności językowej i kulturowej macierzystej populacji, niemniej jednak dla części mieszkańców regionu, nie-Ślązaków, rozpowszechnianie się w ostatnich latach gwary w przestrzeni publicznej oraz działalność śląskich ruchów społecznych jest czymś nowym, niepotrzebnym, bywa też traktowane jako pewnego rodzaju zagrożenie dla polskiej państwowości. Istnieje jednak wiele osób wywodzących się z ludności napływowej, którym zjawisko to jest albo obojętne, albo traktują je jako specyfikę regionu, przyzwyczajają się do niego i nie widzą zagrożenia dla siebie i regionu.

\section{Zakończenie}

Wszystkich Ślązaków - bez względu na opcję narodową - łączy silna więź regionalna, poczucie głębokiej etnicznej swoistości. Śląskość jest najpewniejszym i jedynym niekwestionowanym składnikiem ich tożsamości, 
na którą składają się przede wszystkim: pochodzenie, historia rodziny i regionu, wychowanie w rodzinie i szkole, w tym przekazywanie języka i kultury. Rdzennych mieszkańców Górnego Śląska określa wiele cech, charakterystycznych dla pojęcia etniczności i jej relacji do narodu (Wojakowski 1998; Babiński 1998; Znaniecki 1973; Berlińska 1999; Hroch 2005; Giddens 1999).

Ślązacy definiują swoją tożsamość w sposób bardzo zróżnicowany. Część deklaracji narodowości śląskiej z ostatnich dwóch spisów ludności należałoby potraktować realnie jako dowód na identyfikację narodową, jednak w większości przypadków deklaracje trzeba interpretować jako wyraz przywiązania do śląskości szeroko rozumianej: bardziej w kategoriach etnicznych czy regionalnych niż narodowych. Należy jednak zauważyć, że z socjologicznego punktu widzenia tworzy się nowy naród śląski. Grupa aspirująca do bycia narodem może zostać za taki uznana, jeśli zdecydują się na to ,inni”, przekonani o jej odrębności; ponadto rozstrzygający głos ma wielka polityka. Procesy dotyczące ewolucji tożsamości Ślązaków traktowane są przez władze państwowe, większość ugrupowań politycznych oraz wielu obywateli polskich jako zagrożenie dla jedności i integralności państwa polskiego.

Problem dotyczący odradzania się tożsamości na Górnym Śląsku w dyskursie publicznym, a przy tym konflikt omawianych organizacji śląskich z państwem polskim, należy rozpatrywać na trzech podstawowych płaszczyznach, ściśle powiązanych z przyjętą w naszym kraju koncepcją państwa oraz tożsamości narodowej. Są to: kwestia nadania regionowi statusu autonomicznego; istnienie narodu śląskiego, które budzi największe kontrowersje; kwalifikacja mowy śląskiej i wysiłki organizacji regionalnych podejmowane w celu nadania jej statusu języka regionalnego (Bałdys 2013: 136).

Przywódcy ruchów skupiających Ślązaków (deklarujących narodowość śląską) wyrażają wolę przystąpienia do rozmów z władzami polskimi w celu prawnego uregulowania statusu członków. Domagają się udziału w pracach Komisji Wspólnej Rządu i Mniejszości Narodowych i Etnicznych i zapewne będą coraz częściej skłaniać władze polskie do przeprowadzenia nowelizacji Ustawy o mniejszościach narodowych i etnicznych oraz języku regionalnym, nadającym Ślązakom przynajmniej status mniejszości etnicznej, a śląskiej mowie: języka regionalnego. Nie będzie to 
jednak proste. Ślązacy niewątpliwie będą mieli problemy z ustawowym uznaniem swojej odrębności, uważam jednak, że prędzej czy później zostanie zalegalizowana co najmniej śląska mniejszość etniczna, a ich mowa zyska status języka regionalnego - to jedynie kwestia czasu. Zrozumienie kwestii śląskiej wśród polskiego społeczeństwa, polityków i władz państwowych oraz korzystniejszy klimat społeczno-polityczny w kraju, spowodują zmianę nastawienia.

\section{Literatura}

Babiński G., 1998, Metodologiczne problemy badań etnicznych, Kraków.

Bałdys P., 2013, Bunt Ślazaków? Procesy rewindykacji tożsamości na Górnym Śląsu a idea państwa unitarnego, „Przegląd Zachodni” nr 3, s. 129-155.

Baranowska G., 2013, Uregulowania prawne dotyczace mniejszości narodowych i etnicznych we wspótczesnej Polsce, „Przegląd Zachodni” nr 3, s. 31-45.

Berlińska D., 1999, Mniejszość niemiecka na Śląsku Opolskim w poszukiwaniu tożsamości, Opole.

Giddens A., 1999, Modernity and Self-Identity. Self and Society in the Late Modern Age, Cambridge-Oxford.

Hroch M., 2005, Das Europa der Nationen: die moderne Nationsbildung im europäischen Vergleich, Göttingen.

Jerczyński D., 2013, Józef Kożdoń (1873-1949), przywódca Ślaskiej Partii Ludowej, a kwestia narodowości ślaskiej na Śląsk Cieszyńskim i Opawskim w XIX i XX wieku, Zabrze.

Kaczyński J., 2011, Twierdzenie, że istnieje naród ślaski, to opcja niemiecka, wywiad, $<$ http://wiadomosci.gazeta.pl/wiadomosci/1,114873,9365374,Kaczynski_Twierdzenie_ze_istnieje_narod_slaski_html >, 24.06.2014.

Kłoskowska A., 1996, Kultury narodowe u korzeni, Warszawa.

Kurcz Z., 1993, Przywódcy mniejszości niemieckiej na Śląsku o sobie i swoich zbiorowościach, „Przegląd Zachodni” nr 3, s. 182-198.

Michna E, 2013, Narodowy Spis Powszechny Ludności i Mieszkań w 2011 r. i jego wykorzystanie w polityce tożsamości i walce o uznanie. Casus Ślazaków, „Studia Migracyjne" nr 2, s. 135-171.

Nijakowski L.M., 2006, Domeny symboliczne. Konflikty narodowe i etniczne w wymiarze symbolicznym, Warszawa.

Ossowski S., 1984, O ojczyźnie i narodzie, Warszawa.

Sakson A., 2012, Mniejszość niemiecka w świetle Narodowego Spisu Powszechnego 2011 r., „Biuletyn Instytutu Zachodniego” nr 85, s. 1-5.

Sekuła E.A., Jałowiecki B., Majewski P., Żelazny W., 2012, Być narodem? Ślazacy o Ślasku, Warszawa. 
Szczepański M.S., 1998, Regionalizm górnoślaski: między plemiennościa a systemem globalnym, „Kultura i Społeczeństwo” nr 1, s. 3-22.

Śliz A., Szczepański M.S., 2013, Między etnicznościa a narodowościa. Socjologiczne studium przypadku grupy Górnoślazaków, „Przegląd Zachodni” nr 3, s. 117-128.

Wańkowska-Sobiesiak J., 2006, Za mało na Polaka, za mało na Niemca..., Olsztyn.

Wojakowski D., 1998, Pogranicze polsko-ukraińskie. Lokalność jako czynnik warunkujacy stosunki etniczne, „Studia Socjologiczne” nr 4, s. 66-86.

Znaniecki F., 1973, Socjologia wychowania, Warszawa.

\section{Źródła}

Ludność w województwie opolskim. Stan i struktura demograficzno-społeczna. Narodowy Spis Powszechny Ludności i Mieszkań 2011, 2013a, Urząd Statystyczny w Opolu, Opole.

Ludność w województwie śląskim. Stan i struktura demograficzno-społeczna. Narodowy Spis Powszechny Ludności i Mieszkań 2011, 2013b, Urząd Statystyczny w Katowicach, Katowice.

Ludność. Stan i struktura demograficzno-społeczna. Narodowy Spis Powszechny Ludności i Mieszkań 2011, 2013c, Główny Urząd Statystyczny, Warszawa.

„Newsletter Stowarzyszenia Osób Narodowości Śląskiej” nr 4, 2014.

Raport z wyników. Narodowy Spis Powszechny Ludności i Mieszkań 2011, 2012, Główny Urząd Statystyczny, Warszawa.

Ustawa o mniejszościach narodowych i etnicznych oraz o języku regionalnym z dnia 6 stycznia 2005 r., Dz.U. z 2005 r. Nr 17, poz. 141.

Ustawa o narodowym spisie powszechnym ludności i mieszkań w 2011 r., Dz.U. z 2010 r. Nr 47, poz. 277. 
